\title{
Malaysia's Palm Oil Export to India
}

\author{
Anizah Md Ali * \\ Department of Economics and Agribusiness, School of Economics, Finance and Banking, Universiti Utara \\ Malaysia
}

\begin{abstract}
India is the second-most populous country after China, with an overall population exceeding 1.3 billion. India is the fifth country in the world with the highest import and consumption of world oils and fats. Palm oil has become the main of oil and fats product that is being imported and consumed in India market. India is the major of Malaysia's palm oil export destination. Malaysia's palm oil exports to India market continually increases since the last ten years with an average of more than 2 million tonnes a year. This study attempts to analyse factors that influence the export demand of Malaysia's palm oil to India market. The study applies the ARDL approach for data from the period 1975 - 2018. The study indicates that there are relationships between variables in the short run and long run for the demand of palm oil exports by India. The most significant determinant is attributed to soya bean prices (LPSBR) and population (LPOPI) in both short-run and long run. The export price of palm oil by Indonesia (LCPOPXIR) indicates a positive and significant relationship as Malaysia and Indonesia are competing to penetrate to India market in the long run. However, Malaysia's export price of palm oil has a negative relationship but insignificant. Thus, the findings suggest for non-price strategies in order to increase exports to India market. Non-price strategies such as an increase of quality and the differentiation of product as well as trade deals are the strategies to increase competitiveness and preferences of Malaysia's palm oil in India market.
\end{abstract}

Keywords: ARDL, Palm Oil, India Market, Export

JEL Classification: F23, M11, M14, M16, M19, Q1

Paper Type: Research

\section{INTRODUCTION}

India is the second-most populous country after China, with an overall population of exceeding 1.3 billion. India is a country that occupies the largest part of South Asia. The economy of India is a developing mixed economy. It is the world's seventh-largest economy by nominal gross domestic product (GDP) and the third-largest by purchasing power parity (PPP). The country ranked 139th in per capita GDP (nominal) and 119th in

\footnotetext{
*Corresponding author: E-mail: anizah@uum.edu.my
} 
per capita GDP (PPP) in 2018. India achieved 6-7 percent average GDP growth annually, after the 1991 economic liberalization. Since 2014, India's economy has been the world's fastest-growing major economy, surpassing China (World Economic Outlook October 2018).

The long-term growth prospective of the Indian economy is positive due to its young population, English proficiency, corresponding low dependency ratio, healthy savings and investment rates, and increasing integration into the global economy. India enhanced the World Bank's growth position for the first time in the fiscal year of 2015-2016, during which the economy grew at 7.6 percent. Despite previous reforms, India's economic growth has still being significantly slowed down by bureaucracy, poor infrastructure, and inflexible labour laws (especially the inability to lay off workers in a business slowdown) (Globaltenders.com). India's economy slowed down in 2017, due to shocks of "demonetization" in 2016 and the introduction of Goods and Services Taxes in 2017 (The World Factbook, 2018). Nearly 60 percent of India's GDP has been driven by domestic private consumption and continues to remain as the world's sixth-largest consumer market (Insight Report World Economic Forum, 2018)

India's service sectors are the fastest growing service sectors in the world with an annual growth rate above 9 percent since 2001, which contributed to 57 percent of GDP in 2012-2013. India has become a major exporter of information technology (IT) services, business process outsourcing (BPO) services, and software services with revenue of \$177 billion in the year 2019. The IT industry continues to be the largest private-sector employer in India. India is the second-largest start-up hub in the world with over 3,100 technology start-ups throughout 2018 and 2019. The Indian automobile industry is one of the largest in the world with an annual production of 21.48 million vehicles (mostly two and threewheelers) from 2013 to 2014. India had $\$ 600$ billion worth of the retail market in 2015 and one of the world's fastest-growing e-commerce markets (globaltenders.com.). With regards to oils and fats world trade particularly, India is one of the major producers, importers and consumers of oil and fats in the world.

Global production of fats and oils is led by Asia. Indonesia is the world's largest producer and accounts for more than half of the global production of palm oil. China ranked second in total world production of fats and oils in 2018, and also a large producer of soybean and rapeseed (canola) oils. Malaysia ranked third in world production because of its place as the world's second-largest palm oil producer. India also produces large volumes of canola and butter. Overall, Asia accounted for more than half of the global fats and oils production in 2018 (https://ihsmarkit.com/products/fats-and-oils-industrychemical-economics-handbook.html). India's production of oils and fats increased gradually from 6.7 million tonnes to 10.1 million tonnes for the period of $2000-2018$. The figure is shown in Table 1.

Since 1995, India has been one of the top five consumers of oils and fats. Based on Table 2, for the period of 2000 - 2018, oils and fats consumption in India had increased from 17.8 million tonnes to 24.3 million tonnes. India became the top importer of oil and fats since 2013, which overtook China and the European Union (EU). The volume of import had increased gradually at a value of 14.96 million tonnes (17.08 percent) in the year 2018, Table 3. The main oil and fats consumed and imported by India is palm oil. 
Malaysia's Palm Oil Export to India

Table 1. World Production Oil and Fat (Thousand Tonnes)

\begin{tabular}{lccccccc}
\hline Country & $\mathbf{2 0 0 0}$ & $\mathbf{2 0 0 5}$ & $\mathbf{2 0 1 0}$ & $\mathbf{2 0 1 5}$ & $\mathbf{2 0 1 6}$ & $\mathbf{2 0 1 7}$ & $\mathbf{2 0 1 8}$ \\
\hline Indonesia & 8,620 & 16,458 & 25,647 & 37,943 & 36,626 & 41,651 & 44,407 \\
China, P.R. & 14,947 & 18,832 & 23,256 & 26,543 & 27,065 & 28,334 & 28,262 \\
European Union & 17,083 & 18,414 & 22,598 & 24,341 & 23,921 & 24,482 & 25,057 \\
(EU) & 12,351 & 16,914 & 19,135 & 22,386 & 19,454 & 22,370 & 22,094 \\
Malaysia & 15,613 & 15,992 & 16,088 & 18,608 & 19,806 & 20,111 & 21,117 \\
USA & 5,345 & 7,345 & 8,749 & 10,217 & 10,011 & 10,624 & 11,192 \\
Brazil & 5,651 & 7,378 & 8,537 & 9,484 & 10,271 & 9,896 & 9,156 \\
Argentina & 6,703 & 8,144 & 8,961 & 8,351 & 8,575 & 9,624 & 10,094 \\
India & $\mathbf{2 8 , 4 4 4}$ & 31,614 & 39,596 & 49,693 & 50,297 & 54,879 & 58,698 \\
Others & $\mathbf{1 1 4 , 7 5 7}$ & $\mathbf{1 4 1 , 0 9 1}$ & $\mathbf{1 7 2 , 5 6 7}$ & $\mathbf{2 0 7 , 5 6 6}$ & $\mathbf{2 0 6 , 0 2 6}$ & $\mathbf{2 2 1 , 9 7 1}$ & $\mathbf{2 3 0 , 0 7 7}$ \\
\hline TOTAL & & & & & &
\end{tabular}

Source: Malaysian Oil Palm Statistics, 2014 and 2018.

Table 2. World Consumption Oil and Fat (Thousand Tonnes)

\begin{tabular}{lccccc}
\hline Country & $\mathbf{2 0 1 0}$ & $\mathbf{2 0 1 5}$ & $\mathbf{2 0 1 6}$ & $\mathbf{2 0 1 7}$ & $\mathbf{2 0 1 8}$ \\
\hline China & 32,435 & 36,338 & 36,008 & 37,640 & 37,951 \\
EU & 30,938 & 32,458 & 32,671 & 33,845 & 34,120 \\
India & 17,811 & 22,288 & 23,233 & 24,171 & 24,269 \\
USA & 15,392 & 20,340 & 22,115 & 22,575 & 23,349 \\
Indonesia & 6,349 & 9,004 & 11,336 & 11,435 & 11,381 \\
Brazil & 7,537 & 8,994 & 9,056 & 9,637 & 10,501 \\
Malaysia & 3,751 & 4,784 & 4,470 & 4,728 & 5,371 \\
Pakistan & 3,776 & 4,515 & 4,716 & 4,975 & 5,156 \\
Russia & 3,970 & 4,390 & 4,580 & 4,676 & 4,788 \\
Bangladesh & 1,484 & 2,224 & 2,487 & 2,695 & 2,933 \\
Nigeria & 2,397 & 2,948 & 2,974 & 2,957 & 2,915 \\
Others & 45,373 & 56,034 & 57,637 & 59,843 & 64,741 \\
\hline TOTAL & $\mathbf{1 7 1 , 2 1 3}$ & $\mathbf{2 0 4 , 3 1 7}$ & $\mathbf{2 1 1 , 2 8 3}$ & $\mathbf{2 1 9 , 1 7 7}$ & $\mathbf{2 2 7 , 4 7 5}$ \\
\hline
\end{tabular}

Source: Malaysian Oil Palm Statistics, 2014 and 2018

Table 3. World Major Importers of Oil and Fats (Thousand Tonnes (percentage))

\begin{tabular}{lccccc}
\hline Country & $\mathbf{2 0 0 5}$ & $\mathbf{2 0 1 0}$ & $\mathbf{2 0 1 5}$ & $\mathbf{2 0 1 7}$ & $\mathbf{2 0 1 8}$ \\
\hline India & 5,477 & 9,168 & 15,133 & 15,486 & 14,969 \\
& $(10.75)$ & $(13.77)$ & $(18.22)$ & $(17.77)$ & $(17.08)$ \\
European Union & 8,029 & 10,037 & 11,059 & 12,460 & 12,062 \\
(EU) & $(15.76)$ & $(15.07)$ & $(13.31)$ & $(14.30)$ & $(13.76)$ \\
China & 6,970 & 9,751 & 9,774 & 8,818 & 9,572 \\
& $(13.68)$ & $(14.64)$ & $(11.77)$ & $(10.12)$ & $(10.92)$ \\
USA & 2,190 & 3,498 & 4,559 & 4,893 & 9,572 \\
& $(4.30)$ & $(5.25)$ & $(5.49)$ & $(5.61)$ & $(10.92)$ \\
Pakistan & 1,6781 & 2,1073 & 3,033 & 3,172 & 3,087 \\
& $(3.49)$ & $(3.26)$ & $(3.65)$ & $(3.64)$ & $(3.52)$ \\
Bangladesh & na & 1,438 & 2,067 & 2,452 & 2,469 \\
& & $(2.16)$ & $(2.49)$ & $(2.81)$ & $(2.82)$ \\
\hline TOTAL & $\mathbf{5 0 , 9 6 1}$ & $\mathbf{6 6 , 6 0 1}$ & $\mathbf{8 3 , 0 6 2}$ & $\mathbf{8 7 , 1 4 3}$ & $\mathbf{8 7 , 6 5 3}$ \\
\hline
\end{tabular}

Source: Malaysia Oil Palm Statistics, 2014 and 2018

Based on Table 4, India imported about 3.3 million tonnes of palm oil in 2005. In the year 2018, the amount increased to 8.74 million tonnes. This was followed by the European Union (7.65 million tonnes), China (5.38 million tonnes), Pakistan (3.02 million tonnes) and Bangladesh (1.71 million tonnes). Nonetheless, the consumption of palm oil by India also increased from 3.3 million tonnes to 9.02 million tonnes during that period (Table 5). This 
shows the importance of palm oil in India, despite the fact that the country has regularly changed its import duty on palm oil, to secure its domestic oil, especially coconut oil. Almost 90 percent of palm oil imported was from Malaysia and Indonesia. India mostly imports processed palm oil from Malaysia, while crude palm oil from Indonesia. Indonesia exports remained dominant in India market since 2005, which has taken over Malaysia's position.

Table 4. World Major Importer of Palm Oil (Thousand Tonnes)

\begin{tabular}{lccccc}
\hline Country & $\mathbf{2 0 0 5}$ & $\mathbf{2 0 1 0}$ & $\mathbf{2 0 1 5}$ & $\mathbf{2 0 1 7}$ & $\mathbf{2 0 1 8}$ \\
\hline India & 3,315 & 6,649 & 9,496 & 9,297 & 8,740 \\
European Union (EU) & 4,473 & 5,945 & 7,371 & 7,797 & 7,652 \\
China & 4,320 & 5,823 & 6,030 & 5,196 & 5,380 \\
Pakistan & 1,646 & 2,100 & 2,784 & 2,939 & 3,020 \\
Bangladesh & 931 & 1,065 & 1,453 & 1,535 & 1,710 \\
USA & 420 & 948 & 1,232 & 1,402 & 1,520 \\
Nigeria & na & 799 & 1,440 & 1,429 & 1,300 \\
Others & 11,617 & 13,752 & 18,021 & 19,671 & 20,715 \\
\hline TOTAL & $\mathbf{2 6 , 6 0 2}$ & $\mathbf{3 7 , 0 8 1}$ & $\mathbf{4 7 , 8 2 7}$ & $\mathbf{4 9 , 2 6 6}$ & $\mathbf{5 0 , 0 3 7}$ \\
\hline
\end{tabular}

Source: Malaysia Oil Palm Statistics 2018

Table 5. World Major Consumer of Palm Oil (Million Tonnes)

\begin{tabular}{lccccc}
\hline Country & $\mathbf{2 0 0 5}$ & $\mathbf{2 0 1 0}$ & $\mathbf{2 0 1 5}$ & $\mathbf{2 0 1 7}$ & $\mathbf{2 0 1 8}$ \\
\hline Indonesia & 3,546 & 5,455 & 7,057 & 9,200 & 11,430 \\
& $(10.54)$ & $(11.75)$ & $(11.60)$ & $(14.10)$ & $(16.28)$ \\
India & 3,309 & 6,714 & 9,245 & 9,300 & 9,016 \\
& $(9.83)$ & $(14.47)$ & $(15.19)$ & $(14.25)$ & $(12.84)$ \\
European Union (EU) & 4,368 & 5,754 & 7,250 & 7,564 & 7,589 \\
& $(12.98)$ & $(12.40)$ & $(11.91)$ & $(11.59)$ & $(10.81)$ \\
China & 4,340 & 5,831 & 5,730 & 5,108 & 5,408 \\
& $(21.11)$ & $(18.66)$ & $(14.50)$ & $(12.18)$ & $(11.97)$ \\
Malaysia & 1,965 & 2,065 & 2,917 & 2,859 & 3,372 \\
Pakistan & $(15.00)$ & $(13.63)$ & $(13.67)$ & $(12.26)$ & $(13.47)$ \\
& 1,546 & 1,985 & 2,574 & 2,765 & 2,908 \\
Nigeria & $(4.59)$ & $(4.28)$ & $(4.23)$ & $(4.24)$ & $(4.14)$ \\
& 1,107 & 1,639 & 2,380 & 2,363 & 2,344 \\
USA & $(3.29)$ & $(3.53)$ & $(3.91)$ & $(3.62)$ & $(3.34)$ \\
& 376 & 863 & 1,070 & 1,335 & 1,490 \\
Bangladesh & $(1.12)$ & $(1.86)$ & $(1.76)$ & $(2.05)$ & $(2.12)$ \\
& $n$ & 945 & 1,303 & 1,455 & 1,612 \\
Others & $n a$ & $(2.04)$ & $(2.14)$ & $(2.23)$ & $(2.30)$ \\
& 13,098 & 15,155 & 21,335 & 23,322 & 25,041 \\
TOTAL & $(38.66)$ & $(32.66)$ & $(35.06)$ & $(35.73)$ & $(35.67)$ \\
\hline
\end{tabular}

Source: Malaysia Oil Palm Statistics 2018

In the year 2005, Malaysia palm oil export to India counted 635, 049 tonnes, while Indonesia palm oil export volume counted 2.67 million tonnes. In the year 2018 , Indonesia exported about 6.71 million tonnes of palm oil to India. However, the amount has started to decrease from 2017 with volume counted 7.63 million tonnes. During which, Malaysia exported about 2.02 and 2.51 million tonnes of palm oil in the year 2017 and 2018, respectively. This shows a decreasing trend for Indonesia and the increasing trend for Malaysia, even though the amount of Malaysia's export was smaller than Indonesia's. This is represented in Figure 1. Therefore, based on this situation, this study attempts to analyse the factors that influence the export demand of Malaysia's palm oil to India market. 
The findings of this study are expected to provide useful information for the government and authority organizations as well as the public regarding palm oil export to India market. This is also due to bad campaign of palm oil in the EU and USA.

\section{LITERATURE REVIEW}

There are several studies on demand for palm oil being conducted. The demand can also be expressed as export, import and domestic. In the analysis of Malaysia's palm oil exports, Mohammed and Mohammad (1987) found that palm oil export demand was influenced by lagged exports and economic activities. Mohammed (1988) also found that Malaysia's palm oil export demand was only influenced by the economic activity and soya bean price as a substitute. Meanwhile, Faizah, Ayat and Mohd Nasir (2006) indicate that soya bean price was significant and elastic in all destinations except in China, which was inelastic in the short run.

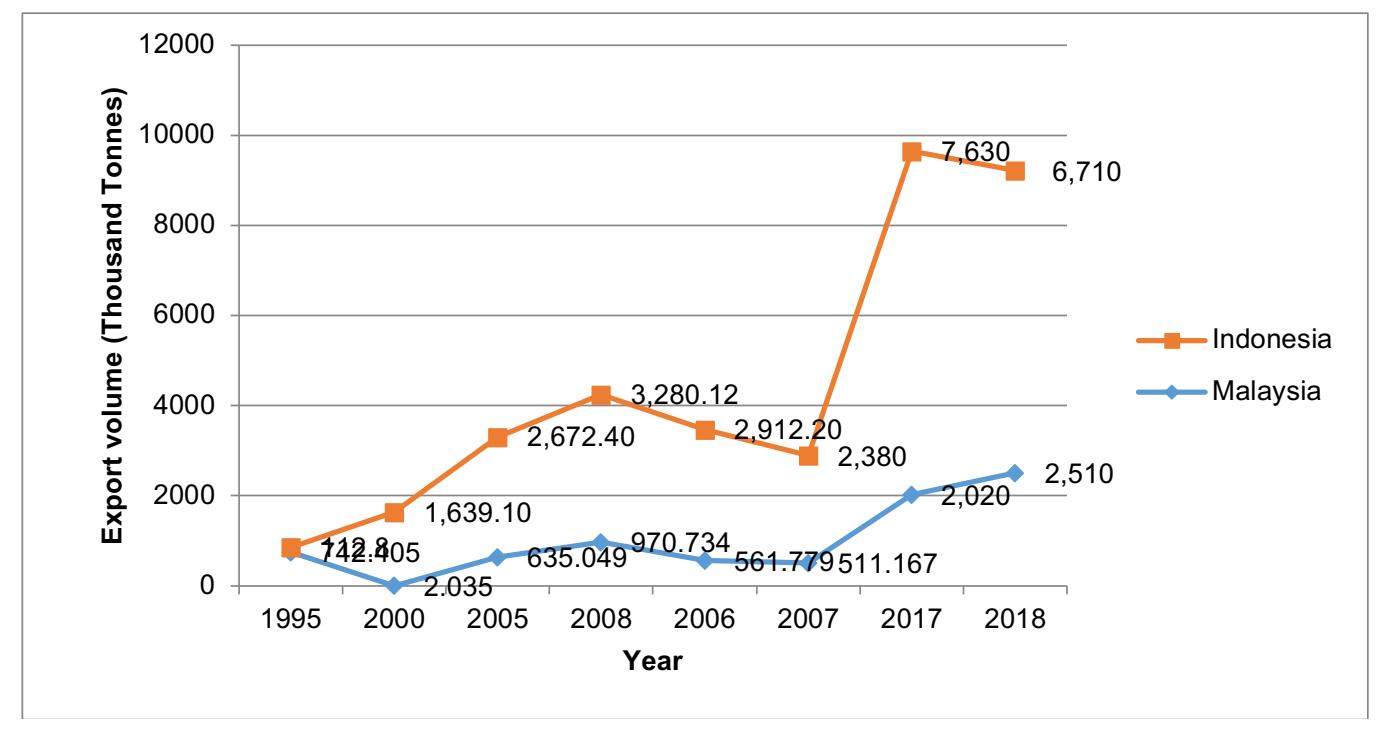

Figure 1. Palm Oil Export to India: 1995 - 2018 (Thousand Tonnes) Source: Malaysia Oil Palm Statistics 2000, 2014 and 2018

While, in the long run, the palm oil price was significant in all destination except in South Korea. Soya bean price was not significant in China and Pakistan. The income per capita was significant in China, Pakistan and India. Consumption of oils and fats was significant in Pakistan and India while the exchange rate was significant in China and South Korea, and inflation was significant in Egypt. Basri et al. (2007) indicated that the export of CPO was significantly influenced by the export policy and lagged export. The export price, however, was insignificant. Export of PPO was influenced by lagged export and soya bean price. World price was negatively related, however insignificant while the crisis was positively related and insignificant. Shri Dewi, Mohammad and Anizah (2007) found that palm oil export demand factors were world palm oil price, world soya bean price and time trend. Haznita (2011) found that the opportunities in palm oil demand in Turkey were due to the growing food industries, the ongoing removal of trans- fat from many consumer products as well as the health concern.

Wong and Muhammad Yusof (2017) also found that Malaysia's palm oil export was significantly affected by world GDP in the long run. However, in the short run, the factors 
were palm oil export price, soya bean price and world GDP. Norhidayu et al. (2018), examined the potential of Malaysian palm oil in the African market. The result showed that there was good potential in West, East and South Africa. With regards of Indonesia's palm oil industry, Ernawati et al. (2006) studied the reduction of export tax and import tariff on Indonesia's palm oil to India, China, Europe and others (ROW). By using the ECM approach, they found that export demand in India was determined significantly positive and elastic by ratios of palm oil to soya bean price, industrial production index and lagged export. However, the exchange rate is insignificant on export demand. Export demand in China was determined significantly positive and elastic by ratios of world palm oil price and soya bean price. However, the export demand was determined positive and insignificant by the industrial production index and negative and insignificant by the exchange rate. In Europe, the determinants were world palm oil price, rapeseed oil price and export lagged. Palm oil export demand in ROW was influenced by world palm oil price, soya bean price, industrial production index and lagged export.

Ernawati (2007) found that Indonesia's palm oil export to India was determined by palm oil, soya bean price ratio, industrial production index and lagged export. The elasticity values are 2.74, 2.69 and 0.69, respectively. Meanwhile, according to Yulisme and Siregar (2007), Indonesian's palm oil export to India and China market were elastic in income and inelastic in price. Ambiyah (2011) found that Indonesia's palm oil export demand was influenced by export price and foreign income. Ariffin and Akyuwen (2011) stated that lagged three-year palm oil price, sunflower price and soya bean price were significant factors for Indonesia's CPO export. Eva and Arif (2017) analysed Indonesia's crude palm oil export by using ARDL approach. The finding suggested that the international CPO price has a negative effect on Indonesia's CPO exports in the short and long run. While CPO production and exchange rate had a significant negative effect on Indonesia's CPO export in both periods. Marizha, Masyhuri and Slamet (2018) analysed the rate of Indonesia's CPO export growth to India by using market share analysis and Error Correction Model (ECM). The analysis shows that the growth rate of Indonesian CPO exports to India fluctuated due to the policy free trade agreement, Indonesia CPO export tax and the economic crisis. The volume of export influenced negatively and significantly in the short and long run. In addition, India's population has also affected the export volume in the long run. Girsang, Sukiyono and Asriani (2018) reported that Indonesia's export on palm oil to Pakistan was significantly influenced by the international price of CPO in the short run. While, in the long run, it was determined by the exchange rate. The result also found that there was no correlation between production CPO and domestic price of CPO in the Pakistan market.

With regards to import demand, Basri et al. (2007) found that economic activity and lagged import had a positive relationship with CPO import. However, real-world price and economic crisis had a negative relationship and insignificant. Export of PPO was affected significantly by lagged export and world soya bean price. Meanwhile, Indonesia's CPO export was positively influenced by soya bean price, production of CPO and lagged export but was negatively influenced by world palm oil price. Amna et al. (2007) analysed Malaysia's palm oil import demands by Algeria, Egypt, Iran Jordan, Libya, Morocco, Arab Saudi, Sudan, Syria and Turkey using ARDL approach. The result explained that lagged of demand is significant in all destinations except in Algeria and Jordan. Current palm oil price was significant in all destinations in the short-run demand. Soya bean price is a substitute to palm oil; thus, it is a significant factor for Malaysia's palm oil demand in Algeria, Egypt, Iran, Jordan, Turkey and Morocco except in Algeria. Corn oil price was significant in Saudi Arabia and Libya, while the rapeseed oil price was significant in Sudan and sunflower price, was significant in Syria. The bad campaign has a negative effect on palm oil import in Algeria and Iran. Nevertheless, promotions had increased the demand 
in Egypt. On the other hand, the Gulf War crisis and trade barrier had reduced the palm oil market in Jordan. In addition, embargo sanctions the import in Libya. Palm oil import demand in Algeria also was influenced by the downward trend in the short and long run. Amna and Fatimah (2008) studied palm oil import demand in the USA, Canada and Mexico. The result shows that palm oil was a significant antecedent in all destination and soya bean oil as a substitute to palm oil. Distinctively, anti-campaign on palm oil has a negative impact on palm oil import in USA and Canada. Amzul (2010) reported that the world's demand for palm oil is due to an increase in the world's income. Therefore, Malaysia and Indonesia should cooperate in order to increase the world demand for palm oil. Amna and Fatimah (2012) studied palm oil import demand in selected EU countries by using ARDL approach. The findings revealed that rapeseed and sunflower oils are substitutes to palm oil in Europe and that palm oil price and industrial production index are important factors. Mohammad (2014) found that the palm oil demand in Turkey expanded due to the large population and higher growth in import and consumption of palm oil. The demand for palm oil in food, oleochemical and other non-food industries increased yearly. Further to this, the empirical result from a study by Kalsom et al. (2018) shows that domestic income and sunflower oil prices had a positive and significant relationship with palm oil demand in the long run. However, palm oil prices showed a significantly negative relationship with palm oil export.

In addition, Ramli, Mohd Nasir and Ahmad (1993) reported that domestic demand was positively influenced by real income and soya bean price and negatively influenced by the real palm oil price. In another study by Amna, Fatimah and Emmy (2016), their results showed that palm oil and substitute oil price and national income are significant antecedents in six Asian countries; India, China, Japan, Bangladesh, Korea and Pakistan. Most of the studies analysed the determinants of palm oil export, import and domestic demand. However, those studies did not focus on the competition between Indonesia and Malaysia. They only focus on the competition between palm oil and soya bean oil, sunflower oil and rapeseed oil. Hence, this study attempts to analyse the competition of palm oil exporter country, which is Malaysia and Indonesia in the India market. India was chosen in this study because this country is a major importer of palm oil in the world.

\section{METODOLOGY AND MODEL: ARDL BOUND TEST}

The demand function for palm oil is a derivation demand which is based on the maximization theory of the firm, Handerson and Quandt, 1980 (Mad Nasir, Zainalabidin and Fatimah, 1988; Mad Nasir and Fatimah 1993 and Mad Nasir et al., 1994). Thus, based on the previous studies, the demand function is expressed as follow (Equation 1):

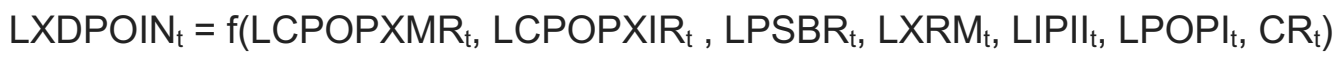

Where,

$\mathrm{LXDPOIN}_{\mathrm{t}}=$ Malaysia's Palm oil export (million tonnes)

$\mathrm{LCPOPXMR}_{\mathrm{t}}=$ Malaysia's export price (US\$/tonnes)

$\mathrm{LCPOPXIR}_{\mathrm{t}}=$ Indonesia's export price (US\$/tonnes)

$\mathrm{LPSBR}_{\mathrm{t}}=$ Price of soya bean (US\$/tonnes)

$\mathrm{LXRM}_{\mathrm{t}}=$ Malaysia's exchange rate (RM/US\$)

$\mathrm{LIPII}_{\mathrm{t}}=$ Industrial production Indexes of India $(2010=100)$

$\mathrm{LPOPI}_{\mathrm{t}}=$ Population of India (million people)

$\mathrm{CR}_{\mathrm{t}}=$ Crisis (Dummy $1=$ Crisis; $0=$ No Crisis) 
This study uses time-series data. Hence to avoid spurious regression, ARDL approach is being applied in this study. ARDL approach was introduced by Pesaran, Shin and Smith (1996) and Pesaran et al. (2001) to examine the co-integration characteristics of the estimated equation. An advantage of the ARDL approach is that it can be used whether the variables are I(0) or I(1) as well mix of both, but not I(2). This approach allows for testing of long-run relationship and estimating the long-run parameter (Egwuma et al., 2016). By using ARDL approach, it is possible to have different variables with different optimal lags, where it is impossible to conduct with the standard co-integration test. Hence, the model can be used with limited sample data (Kalsom et al., 2018). The estimated ARDL model is as follows (Equation 2):

$$
\begin{aligned}
\Delta \text { LXDPOIN }_{t}= & \alpha_{O}+\sum_{h=1}^{k} \beta_{1 h} \Delta L C P O P X R_{t-h}+\sum_{i=1}^{m} \beta_{2 i} \Delta L C P O P X I R_{t-i} \\
& +\sum_{j=1}^{n} \beta_{3 j} \Delta L P S B R_{t-j}+\sum_{l=1}^{p} \beta_{4 l} \Delta L X R M_{t-l}+\sum_{w=1}^{q} \beta_{5 w} \Delta L I P I I_{t-w} \\
& +\sum_{v=1}^{r} \beta_{6 v} \Delta L P O P I_{t-v}+\sum_{z=1}^{s} \beta_{7 z} \Delta C R_{t-z}+\gamma_{1} L X D P O I N_{t-1} \\
& +\gamma_{2} L_{C P O P X M R_{t-1}}+\gamma_{3} L C P O P X I R_{t-1}+\gamma_{4} L P S B R_{t-1}+\gamma_{5} L X R M_{t-1} \\
& +\gamma_{6} \text { LIPII }_{t-1}+\gamma_{7} \text { LPOPI }_{t-1}++\gamma_{8} \text { CR }_{t-1}+\varepsilon_{t}
\end{aligned}
$$

Where;

$\alpha, \beta$ and $\gamma=$ parameter to be estimated

$\mathrm{LXDPOIN}_{\mathrm{t}}=$ Malaysia's Palm oil export (million tonnes)

$\mathrm{LCPOPXMR}_{\mathrm{t}}=$ Malaysia's export price (US\$/tonnes)

$\mathrm{LCPOPXIR}_{\mathrm{t}}=$ Indonesia's export price (US\$/tonnes)

$\mathrm{LPSBR}_{\mathrm{t}}=$ Price of soyabean (US\$/tonnes)

$\mathrm{LXRM}_{\mathrm{t}}=$ Malaysia's exchange rate (RM/US\$)

$\mathrm{LIPII}_{\mathrm{t}}=$ Industrial production Indexes of India $(2010=100)$

$\mathrm{LPOPI}_{\mathrm{t}}=$ Population of India (million people)

$\mathrm{CR}_{\mathrm{t}}=$ Crisis (Dummy $1=$ Crisis; $0=$ No Crisis)

$\varepsilon_{\mathrm{t}}=$ Error term

\section{SOURCE OF DATA}

The data used in this study are from the annual basis of secondary data for the period 1975 - 2018. The data on palm oil import, soya bean price and palm oil price were taken from statistical books and report published, and the website of Ministry of Plantation and Commodities Malaysia (MPIC), Malaysian Palm oil Board (MPOB) in various series and year. The data and information were also gathered from Pusat Penelitian Kelapa Sawit, Indonesia, Departement Pertanian Indonesia, Directorat Jenderal Perkebunan and Oil World websites.

\section{EMPIRICAL RESULT}

\subsection{Bound Testing}

Bound testing for co-integration through ARDL approach is estimated using equation (2). It involved a comparison between F-statistics and F critical value. The calculated F- 
statistics are presented in Table 6, with the corresponding critical value developed by Pesaran et al. (2001). The computed value of $F$ statistics is 6.1630 . This value is higher than the upper bound critical value at 1 percent significant level. According to the rule of hypothesis testing, if the calculated value of test statistics is higher than the critical value, researchers can reject the null hypothesis of the non-co-integration among variables XDPOIND, CPOPXMR, CPOPXIR, PSBR XRM, IPII, POPI and CR. Hence it is confirmed that these variables have a long-run relationship or they are co-integrated. Conversely, the serial autocorrelation was determined by the Breusch-Godfrey (BG) LM test. The result shows the score of 0.1118 with probability value 0.8207 , which is greater than 0.05 of the value of the LM test at the 95 percent confidence level. This shows the absence of a serial correlation. The result is presented in Table 7.

Table 6. ARDL Bound Test of Cointegration

\begin{tabular}{lccc}
\hline & Significance & Lower Bound (I0) & Upper Bound (I1) \\
\hline F - statistics & $1 \%$ & 2.96 & 4.26 \\
6.1630 & $2.5 \%$ & 2.6 & 3.84 \\
& $5 \%$ & 2.32 & 3.5 \\
& $10 \%$ & 2.03 & 3.13 \\
\hline
\end{tabular}

Table 7. Test for Serial Autocorrelation

\begin{tabular}{lcc}
\hline Test & Statistics (F) & Probability \\
\hline Breusch-Godfrey (BG) LM & 0.1118 & 0.8207 \\
\hline
\end{tabular}

\subsection{Long Run Estimation}

The empirical result of Malaysia's palm oil export to India market for a long run model is presented in Table 8. The result indicates that palm oil export is positively related to Indonesia export price (CPOPXIR), and it is significant. Positive relationship means that Indonesia and Malaysia as exporters are substitutes exporters in India market. Therefore, Malaysia and Indonesia are competing in the India market. With1 percent increase in Indonesia's palm oil price, Malaysia's palm oil export to India will increase by 4 percent. Thus, the increase of Indonesia's palm oil export price is an advantage to Malaysia in increasing the export volume of palm oil to India market. India maintains its position as the largest Malaysian palm oil export market for the fifth year since 2014. In 2018 the volume of export counted about 15.2 percent of global palm oil export (Malaysian Palm Oil Statistics, 2018).

Table 8. Estimated long-run coefficients using ARDL Approach

\begin{tabular}{lccc}
\hline Variable & Coefficient & t-Statistic & Prob. \\
\hline LCPOPXMR & -1.5164 & -1.2633 & 0.2181 \\
LCPOPXIR & 4.0009 & $2.2282^{* *}$ & 0.0351 \\
LPSBR & 1.9905 & $2.1442^{* *}$ & 0.0419 \\
LXRM & 4.7662 & $2.2012^{* *}$ & 0.0372 \\
LIPII & -6.8764 & -1.2019 & 0.2407 \\
LPOPI & 48.7186 & $1.7343^{*}$ & 0.0952 \\
CR & 0.6674 & 1.1271 & 0.2704 \\
C & -654.350 & -1.7515 & 0.0921 \\
\hline Note: ${ }^{* *}$ Significant at 1 percent, ${ }^{* *}$ Significant at 5 percent, ${ }^{*}$ Significant at 10 percent &
\end{tabular}

Exchange rate (LXRM) is a significant factor and has a positive relationship with coefficient or elasticity is 4.7662 . Thus, in the long run, with a 1 percent increase in the exchange rate, the export of palm oil leads to increase by 4.7 percent. According to economic theory, 
the exchange rate and export have a positive relationship. An increase in the exchange rate means that the domestic products are relatively cheaper, thus leading to an increase in exports (Froyen, 2013). This finding is consistent with Faizah, Ayat and Mohd Nasir (2006), Ernawati et al. (2006) and Girsang, Sukiyono and Asriani (2018).

Soya bean price (LPSBR) also has a positive relationship, and it is significant at 5 percent. The positive relationship means that palm oil and soya bean are substitutes. The elasticity value is 1.99. It implies that with a 1 percent increase in soya bean price, the quantity of palm oil export increases by 1.99 percent. This result is parallel with previous studies such as Mohammed (1988), Faizah, Ayat and Mohd Nasir (2006), Basri et al. (2007), Shri Dewi, Mohammad and Anizah (2007), Ernawati et al. (2006) and Wong and Muhammad Yusof (2017).

Population (LPOPI) is a significant factor at 10 percent with a coefficient value 48.7186. It means that a 1 percent increase in population will lead to an increase in palm oil export by 48.72 percent. This result is consistent with Mohammad (2004) and Marizha, Masyhuri and Slamet (2018). Industrial production indexes (LIPII) that represent India's economic activity has a negative relationship and is insignificant. However, Malaysia's export price (LCPOPXMR) and crisis (CR) are insignificant factors even though it is positively related. This finding is consistent with Basri et al. (2007).

\subsection{Short Run Error Correction Models (ECM)}

ECM from ARDL model is shown in Table 9. As presented in Table 9, the lagged error correction terms (ECT) are statistically significant and negative relationships are being expected. Based on Granger Representation Theorem (Granger, 1983 and Engle and Granger, 1983), the existence of a long-run relationship among variables implies the existence of a valid error correction representation and vice versa. The result of this study on lagged ECT is $(-0.45)$ implies that the speed of adjustment to equilibrium is at the rate of 0.45 percent after the shock. The result also indicates that lagged of palm oil export price of Indonesia (LCPOPXIR(-1)) has a negative relationship, and it is significant.

Table 9. Error Correction Represented For the Selected ARDL Model $(1,0,2,1,0,2,0,2)$

\begin{tabular}{lccc}
\hline Variable & Coefficient & t-Statistic & Prob. \\
\hline D(LCPOPXMR) & -0.6893 & -1.2832 & 0.2112 \\
D(LCPOPXIR) & -0.6286 & -1.3524 & 0.1884 \\
D(LCPOPXIR(-1)) & -1.2349 & $-2.8194^{* *}$ & 0.0093 \\
D(LPSBR) & 0.9048 & $2.2497^{* *}$ & 0.0335 \\
D(LXRM) & 0.7305 & 0.6086 & 0.5483 \\
D(LIPII) & 8.3144 & $2.6728^{* *}$ & 0.0131 \\
D(LIPI(-1)) & 7.3273 & $2.2725^{* *}$ & 0.0319 \\
D(LPOPI) & 22.1441 & $1.8281^{*}$ & 0.0795 \\
D(CR) & 0.1842 & 1.0951 & 0.2839 \\
D(CR (-1)) & -0.3951 & $-2.2589^{* *}$ & 0.0329 \\
ECT $(-1)$ & -0.4545 & $-4.1671^{* * *}$ & 0.0003 \\
\hline
\end{tabular}

Note: ${ }^{* *}$ Significant at 1 percent, ${ }^{* *}$ Significant at 5 percent, ${ }^{*}$ Significant at 10 percent

Therefore, it implies that Malaysia and Indonesia are complementary to each other in the short run. Thus, if the lagged of Indonesia's palm oil export price increases 1 percent, Malaysia's export volume will decrease by 2.82 percent. Industrial production indexes (LIPII) which are a proxy for India's economic activity, has a positive relationship, and it is significant. Thus, an increase in the economic activity of 1 percent leads to an increase in Malaysia's palm oil export to India by 8 percent in the current year and 7.32 percent for the lagged year. The result is consistent with Ernawati et al. (2007). Meanwhile, the price 
of soya bean (LPSBR) is positively related to export. It shows that palm oil and soya bean became substitutes in the short run. This finding is parallel with Wong and Muhammad Yusof (2017). Similarly, the population also has a positive effect on export palm oil to India.

Nonetheless, lagged of economic crisis (CR(-1)) has a negative effect on Malaysia's palm oil export to India. It means that in the short run, the lagged economic crisis reduces palm oil export by 0.39 percent. However, the exchange rate (LXRM), palm oil export price of Malaysia (LCPOPXMR) and palm oil export price of India (LCPOPXIR) are not significant factors in the short run.

\section{CONCLUSION}

The study indicates that there are relationships between the variables of Malaysia's export demand of palm oil to India market in the short run and long run. Based on the results of the analysis, the most significant determinant is attributed to soya bean price (PSBR) and population (POPI) in both short-run and long run. The export of Malaysia's palm oil to India market continues to increase in line with the increase of soya bean price and population. The export price of Indonesia's palm oil is positively related and significant, which indicates that Malaysia and Indonesia are competing to penetrate into India's market in the long run, while becoming complements in the short run. However, Malaysia's export price of palm oil is negatively related but insignificant. Thus, the findings suggest for a non-price strategy to reduce the export price in order to increase export to India market. The non-price strategies are such as increasing the quality and the differentiation of product as well as conducting trade dealings to increase the competitiveness and preferences of Malaysia's palm oil in India market.

\section{REFERENCES}

Ambiyah Abdullah, (2011). Determinants of Indonesian Palm Oil Export: Price and Income Elasticity Estimation. Trends in Agricultural Economics, 4(2), 50-57.

Amna Awad Hameed \& Fatimah Mohamed Arshad. (2012). The Palm Oil Import Demand in Selected European Countries: A Cointegration Analysis.

Amna Awad, Fatimah Mohammed Arshad, Mad Nasir Shamsudin \& Zulkornain. (2007). The Palm Oil Import Demand in Middle East and North African (MENA) Countries. Journal of International Food \& Agribusiness Marketing, 19(2/3).

Amna Awad Abdel Hameed \& Fatimah Mohammed Arshad, (2008). Future trends of palm oil import demand in North America, In Alias Radam \& Rusli Yaacob (eds). The Malaysian agricultural sector: Strategies and challenges. UPM Press, Serdang, 2008.

Amna Awad Abdel Hameed, Fatimah Mohamed Arshad \& Emmy Farha Alias. (2016). Assessing Dynamics of Palm Oil Import Demand: The Case of Six Asian Countries. Journal of Food Products Marketing, 1-19.

Amzul Rifin. (2010). An analysis of Indonesia's palm oil position in the world market: A two stage demand approach. Oil Palm Industry Economic Journal, 10(1).

Arifin Indra Sulistyanto \& Akyuwen, R. (2011). Factors affecting the performance of Indonesia's crude palm oil export. International Conference on Economics and Finance Research. IPEDR, 4. Press, Singapore

Basri Abdul Talib, Mohd Fauzi Mohd Jani, Mohd Noor Mamat \& Rosli Zakaria. (2007). Impact assessment of liberalizing trade on Malaysian crude palm oil. Oil Palm Industry Economic Journal, 7(1).

Departemen Pertanian Indonesia [Palm Oil Statistics Book]. Direktorat Jenderal Perkebunan. Retrieved from http://203.190.36.131/tinymcpuk/gambar/file/statistik/2017/Kelapa-Sawit-2015-2017.pdf

Departmen Pertanian Indonesia [Agriculture Department of Indonesia]. Retrieved from http://www.deptan.go.id/index1.php.

Economy of India. Retrieved from https://en.wikipedia.org/wiki/Economy_of_India

Egwuma, H, Mad Nasir Shamsudin, Zainalabidin Mohamed, Nitty Hirawaty Kamarulzaman \& Wong, K.K.S. (2016). A model for the palm oil market in Nigeria: An econometrics approach. International Journal of Food and Agricultural Economics, 4(2), 69-85.

Engle, R. F. \& Granger, C. W. J. (1987). Co-integration and error correction: Representation, estimation and testing. Econometrica, 55, 251-276. 
Ernawati, et al. (2006). Afta and its implication to the export demand of Indonesian palm oil. Jurnal Agro Ekonomi, 24(2), 115-132.

Ernawati Munadi. (2007). Penurunan pajak eskport dan dampaknya terhadap ekspor minyak kelapa sawit Indonesia ke India (pendekatan Error Correction Model). Informatika Pertanian, 16(2), 1019-1036.

Eva Nurul Huda \& Arif Widodo (2017). Determinan dan stabiliti ekspor crude palm oil Indonesia. Jurnal Ekonomi dan Bisnis, 20(1).

Faizah Shariff, Ayat K AB Rahman \& Mohd Nasir Amiruddin. (2006). The elasticity of foreign demand for Malaysia palm oil. Oil Palm Industry Economic Journal, 6(2), 1-6.

Froyen, R. T. (2013). Macroeconomics. Theories and Policies. 10 $0^{\text {th }}$ Edition. England: Pearson Education Limited.

Girsang, L., Sukiyono, K. \& Putri Suci Asriani. (2018). Error correction model for Pakistan export demand for Indonesia's crude palm oil (CPO) (2018). Agritropica: Journal of Agricultural Sciences, 1(2), 68-67.

Granger, C.W.J. (1983). Cointegrated variables and error correcting models. University of California, San Diego. Discussion Paper, 83-113.

Haznita, H. (2011). Growing demand for palm oil in Turkey- A positive development for MPO. Malaysia Palm Oil Fortune, 9(1), 7-11.

IndexMundi. (2019). IndexMundi-Country Facts. Retrieved from htttp://www.indexmundi.com

India Economy, Business Opportunity in.Retrieve from https://www.globaltenders.com/economy-of-india.php/

Insight Report World Economic Forum (2018). Future Consumption in Fast-Growth Consumer Market: India. Retrieve from http://www3.weforum.org/docs/WEF_Future_of_Consumption_FastGrowth_Consumers_mark.

Mad Nasir Shamsudin, Zainalabidin Mohamed \& Fatimah Mohd. Arshad (1988). Selected factors affecting palm oil prices. Malaysian Journal of Agricultural Economics, 5, 21-29.

Mad Nasir Shamsudin \& Fatimah Mohd Arshad, (1993). Malaysian palm oil market model. In Fatimah Mohd Arshad, Mad Nasir Shamsudin \& Mohd Shahwahid Othman (eds.). Malaysian Agricultural Commodity Forecasting And Policy Modeling, 1 - 12. Universiti Pertanian Malaysia

Mad Nasir Shamsudin, Fatimah Mohd. Arshad \& Fauziah Abu Hassan, (1997). The effect of export duty liberalization on the Malaysian palm oil industry. In 22, World Congress and Exhibition of the International Society for Fat Research (ISF). September 8-12, 1997, Kuala Lumpur.

Mad Nasir Shamsudin, Fatimah Mohd Arshad, Zainal Abidin Mohamed \& Abdul Rahman Lubis, (1994). A Market Model for Malaysian Palm Oil Industry. The Malaysian Journal of Agricultural Economics, 11, 81 102.

Malaysian Palm Oil Board (MPOB). (2015). Malaysia oil palm statistics 2014. 32th edition. Kuala Lumpur: Ministry of Plantation Industries and Commodities. (2019). Malaysia oil palm statistics 2018. 38th edition. Kuala Lumpur: Ministry of Plantation Industries and Commodities.

(2015). Review of the Malaysian oil palm industry 2014. Ministry of Plantation Industries and Commodities.

(2019). Review of the Malaysian oil palm industry 2018. Ministry of Plantation Industries and Commodities.

Mohammed bin Yusoff. (1988). Production and trade model for the Malaysian palm-oil industry. ASEAN Economic Bulletin. November 1988.

Mohamed Bin Yusoff \& Mohamad Bin Salleh. (1987). The elasticities of supply and demand for Malaysian primary commodity exports. Malaysian Journal of Agricultural Economics, 4.

Oil world. Oil world annual. ISTA Mielke GmbH. Hamburg. Various issues. Retrieve from https://www.oilworld.biz/t/publications/data-base

Pesaran, M. H, Shin, Y., \& Smith, R.J. (1996). Testing for the existence of a long run relationship. (no. 9622). Faculty of Economics, University of Cambridge.

Pesaran et al. (2001). Bound testing approaches to the analysis of level relationship. Journal of Applied Econometrics, 16, 289-326. https://doi.org/10.1002/jae.616

Kalsom Zakaria, Balu, N., Norhanani Mohd Baharim \& Norrafidah Mohd Rapiee. (2018). Demand for palm oil in Turkey. Oil Palm Industry Economic Journal, 18(1).

Major Fats and Oils Industry Overview - Chemical Economics. Retrieved from https://ihsmarkit.com/products/fats-and-oils-industry-chemical-economics-handbook.html

Marizha Nurcahyani, Masyhuri \& Slamet Hartono (2018). The export supply of Indonesian crude palm oil (CPO) to India. Agro Ekonomi, 29(1), 18-31.

Mohammad Suhaili (2014). Great potential to expand palm oil market in 2015. Regional Workshop on: Palm Oil Trade Fair and Seminar (POTS), Kuala Lumpur 2014. MPOC.

Norhidayu, A., Kalsom Zakaria, Kamalrudin Mohamed Salleh, Balu, N., Norrafidah Mohd Rapiee \& Nur Asmuni Che Dir. (2018). Market potential for Malaysian palm oil exports to Africa. Oil Palm Industry Economic Journal, 18(2). 
Ramli Abdullah, Mohd Nasir Hj. Amiruddin \& Ahmad Ibrahim. (1993). An Econometric model simulating the Malaysian palm oil market. PORIM Bulletin No. 26 May 1993.

Shri Dewi Subramaniam, Mohammad Haji Alias \& Anizah Md Ali. (2007). Rising ascending in Indonesia production: impact on the Malaysian palm oil market. Kinabalu Journal of Business \& Social Sciences, 13.

The World Factbook - Central Intelligence Agency. Retrieve from www.cia.gov

Wong, K.K.S \& Mohammad Yusof Ahmad (2017). Factor influencing Malaysian palm oil export demand in long run and short run. International Journal of Business and Management, 1(2), 204-210.

World Economic Outlook October 2018: Report for Selected Countries and Subjects. International Monetary Fund (IMF). Retrieved from https://www.imf.org/en/Publications/WEO//ssues/2018/09/24/worldeconomic-outlook-october-2018

Yulisme \& Hermanto Siregar (2007). Determinant factors of Indonesia palm oil export to major importing countries: An Error Correction Model analysis. Economics and Finance in Indonesia, 55(1), 65-88. 